\title{
Kisspeptin activates the hypothalamic-adenohypophyseal- gonadal axis in prepubertal ewe lambs
}

\author{
J S Redmond ${ }^{1}$, G G Macedo ${ }^{1,2}$, I C Velez ${ }^{1,3}$, A Caraty ${ }^{4}$, G L Williams ${ }^{1,3}$ \\ and $M$ Amstalden ${ }^{1}$ \\ ${ }^{1}$ Department of Animal Science, Texas A\&M University, College Station, Texas 77843, USA, ${ }^{2}$ Federal University of \\ Viçosa, Viçosa, Minas Gerais 36570, Brazil, ${ }^{3}$ Texas AgriLife Research, Beeville, Texas 78102, USA and ${ }^{4}$ Physiologie \\ de la Reproduction et des Comportements, INRA/CNRS/Université de Tours/Haras Nationaux, Nouzilly \\ 37380, France \\ Correspondence should be addressed to M Amstalden; Email: m.amstalden@tamu.edu
}

\begin{abstract}
The onset of puberty in mammals involves an increase in the pulsatile release of GNRH and LH. The KISS1 gene is essential for pubertal development, and its product, kisspeptin, stimulates the release of LH. The objective of this study was to determine the effects of kisspeptin in the hypothalamic-adenohypophyseal-gonadal axis of prepubertal ewe lambs. Ewe lambs (28 weeks of age) were treated intravenously with saline (control, $n=6)$ or kisspeptin ( $20 \mu \mathrm{g}$ kisspeptin; $n=6)$ every hour for 24 h. Kisspeptin stimulated pulse-like release of LH within 15 min following injections, and increased the frequency and amplitude of LH pulses, and mean circulating concentrations of $\mathrm{LH}$ and estradiol. A surge-like release of $\mathrm{LH}$ was observed in four kisspeptin-treated lambs beginning $17 \mathrm{~h}$ after the onset of treatment, and all four lambs had elevated circulating concentrations of progesterone within 5 days post-treatment. However, circulating concentrations of progesterone decreased within 2 days after the initial rise in three of the four ewe lambs, indicating that induced luteal activity was of short duration. The proportion of lambs that were pubertal (defined by circulating concentrations of progesterone above $1 \mathrm{ng} / \mathrm{ml}$ for at least 7 days) by 35 weeks of age (8/11) and the mean age at puberty (32 \pm 1 weeks) for those reaching puberty within the experimental period did not differ between treatments. Results support a role for kisspeptin in the activation of the hypothalamic-adenohypophyseal axis leading to the onset of puberty in ewe lambs.
\end{abstract}

Reproduction (2011) 141 541-548

\section{Introduction}

Maturation of the reproductive neuroendocrine axis in mammalian species is characterized by an increase in the frequency of episodic release of LH (Foster et al. 1975, Huffman et al. 1987, Ebling et al. 1990) in response to increased GNRH release from hypothalamic neurons (Watanabe \& Terasawa 1989). Sustained elevation of circulating concentrations of LH supports the final stages of follicular development, steroidogenesis and ultimately, ovulation (Foster \& Jackson 2006). Although pubertal activation of pulsatile GNRH release has been well characterized (Wildt et al. 1980, Kinder et al. 1995), the mechanisms and neuronal pathways leading to increased frequency of GNRH release during the peripubertal period remain unclear. Kisspeptin, a peptide with potent stimulatory effects on the release of GNRH and LH (Matsui et al. 2004, Messager et al. 2005, Kadokawa et al. 2008, Lents et al. 2008, Magee et al. 2009 , Smith et al. 2009b), plays a critical role. Kisspeptin (d'Anglemont de Tassigny et al. 2007, Lapatto et al. 2007) and its receptor (de Roux et al. 2003, Seminara et al. 2003) are essential for normal onset of puberty. Administration of kisspeptin to prepubertal rats advances the time of vaginal opening (Navarro et al. 2004b), suggesting that kisspeptin can hasten maturation of reproductive function. Moreover, kisspeptin prevents the delay in puberty caused by undernutrition in rats (Castellano et al. 2005).

The effects of kisspeptin on reproductive function seem to occur primarily by stimulation of GNRH secretion (Gottsch et al. 2004, Navarro et al. 2004a, Messager et al. 2005), although direct effects at the level of the adenohypophysis have been demonstrated (Suzuki et al. 2008). In mature ewes, continuous infusion of kisspeptin sustains elevated circulating concentrations of $\mathrm{LH}$ for $24 \mathrm{~h}$ and stimulates ovulation during the anestrous season (Caraty et al. 2007). The ability of kisspeptin to stimulate $\mathrm{LH}$ release in prepubertal females (Navarro et al. 2004b, Kadokawa et al. 2008, Lents et al. 2008) indicates that exogenous kisspeptin can override the deficiency in $\mathrm{LH}$ release characteristic of immature states. In this study, we determined the effects of 

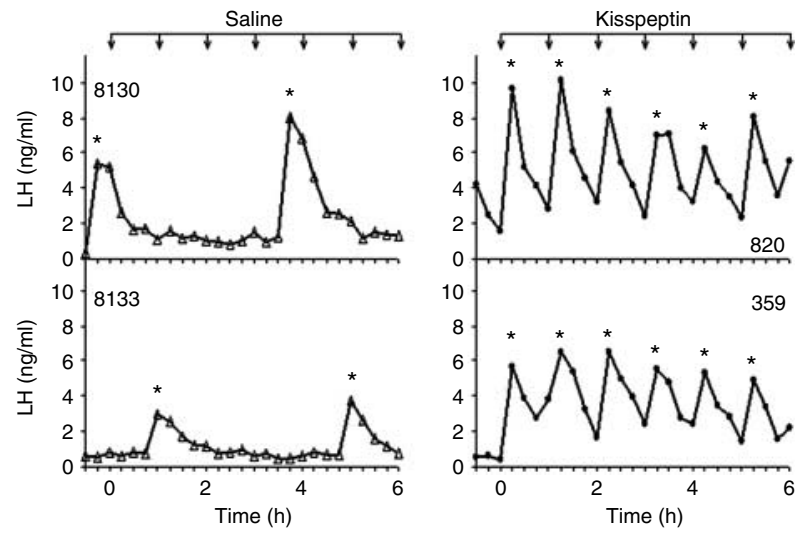

Figure 1 Patterns of LH release in representative saline- (control) and kisspeptin-treated ewe lambs during period I ( $0-6$ h) of the experiment. Asterisks indicate detected pulses of $\mathrm{LH}$; arrows indicate the time of injections of saline (control) or kisspeptin. Note that in kisspeptintreated lambs, a pulse of LH was observed following every injection of kisspeptin.

intermittent injections of kisspeptin on the release of $\mathrm{LH}$ in prepubertal lambs. We also determined whether repeated hourly administration of kisspeptin leads to synchronized hourly release of $\mathrm{LH}$ and stimulates follicular growth, ovulation, and initiation of regular reproductive cycles.

\section{Results}

Elevated concentrations of progesterone were observed in one control ewe on the first day of the experiment, and data obtained from her were eliminated from further analyses. Mean \pm s.E.M. body weight at the onset of treatments was $42.5 \pm 1.7 \mathrm{~kg}$ and did not differ among groups.

Mean concentrations of $\mathrm{LH}$ prior to the onset of treatments (period 0 ) did not differ between groups and averaged $1.9 \pm 0.4 \mathrm{ng} / \mathrm{ml}$. As expected, control ewes exhibited infrequent pulses of $\mathrm{LH}$ characteristic of prepubertal ewes (Fig. 1, Table 1). In kisspeptin-treated ewes, a pulse of LH was observed within 15 min after every injection (Fig. 1), resulting in an increased $(P<0.02)$ frequency of $\mathrm{LH}$ pulses compared with controls during the first $6 \mathrm{~h}$ after the onset of treatments (Table 1). Similarly, mean concentrations of $\mathrm{LH}$ and mean amplitude of $\mathrm{LH}$ pulses were greater $(P<0.005)$ in kisspeptin-treated lambs than those in controls during period I (Table 1).

During period III (18-24 h after the onset of treatments), the pattern of LH release in control ewe lambs remained similar to that of period I, with only infrequent episodes of $\mathrm{LH}$ release observed. In the kisspeptintreated group, four of six ewe lambs were observed to exhibit a surge release of $\mathrm{LH}$ beginning $\sim 20 \mathrm{~h}$ after the onset of kisspeptin injections (Fig. 2), while none of the saline-treated ewe lambs had such response $(P<0.05)$. The interval from the start of treatment to the onset of
LH surges averaged ( \pm S.E.M.) $21 \pm 2.3 \mathrm{~h}$. The mean maximum concentration of $\mathrm{LH}$ observed during the surge was $22 \pm 13 \mathrm{ng} / \mathrm{ml}$. The duration of the LH surge lasted $\sim 12 \mathrm{~h}$ (Fig. 3).

Mean concentrations of estradiol $\left(\mathrm{E}_{2}\right)$ were low at the beginning of the treatments and did not differ between the two groups (Fig. 4). However, concentrations of $E_{2}$ increased in kisspeptin-treated ewes and were greater $(P<0.02) 18 \mathrm{~h}$ after initiation of injections than those in saline-treated ewes (Fig. 4). Ewes observed to exhibit a LH surge (four of six ewe lambs) had elevated concentrations of progesterone (above $1 \mathrm{ng} / \mathrm{ml}$ ) 5 days after the onset of treatments, indicating that the surge of LH caused ovulation and/or follicle luteinization. During the experiment, two of the kisspeptin-treated ewe lambs did not exhibit surge release of $\mathrm{LH}$, although they continued to respond to the kisspeptin injections with a pulse-like release of $\mathrm{LH}$ within 15 min after injections (Fig. 2) and had elevations in concentrations of circulating $E_{2}$. None of the saline-treated ewe lambs were observed to have elevated progesterone in this period $(P<0.05)$.

In three of the four kisspeptin-treated lambs that exhibit luteal activity after treatments, concentrations of progesterone were elevated only briefly and decreased below $1 \mathrm{ng} / \mathrm{ml} 2-3$ days after the initial rise. Circulating concentrations of progesterone remained elevated for an extended period in only one of the four kisspeptintreated ewe lambs that had exhibited luteal activity. No control ewe lambs exhibited elevated concentrations of progesterone within 5 days following saline injections. The proportion of ewes determined pubertal in each group by 35 weeks of age, defined as ewes exhibiting circulating concentrations of progesterone above $1 \mathrm{ng} / \mathrm{ml}$ for at least three consecutive samples collected every 3 days, did not differ between groups. Overall, eight of eleven lambs were pubertal by the end of the experiment.

\section{Discussion}

The ability of kisspeptin to stimulate the release of $\mathrm{LH}$ in prepubertal female mammals has been demonstrated in rats (Navarro et al. 2004b), heifers (Kadokawa et al. 2008), and gilts (Lents et al. 2008). In this study, we

Table 1 Mean ( \pm S.E.M.) circulating concentrations of LH, and frequency and amplitude of LH pulses in saline- (control) and kisspeptin-treated ewe lambs during period I ( $0-6$ h) of the experiment. Mean concentrations of $\mathrm{LH}$ as well as frequency and amplitude of $\mathrm{LH}$ pulses were greater in kisspeptin-treated ewes than those in controls.

\begin{tabular}{lcc}
\hline & Control $(n=5)$ & Kisspeptin $(n=6)$ \\
\hline Concentrations (ng/ml) & $2.3 \pm 0.1^{\mathrm{a}}$ & $4.5 \pm 0.2^{\mathrm{b}}$ \\
Frequency of pulses (pulses/6 h) & $3.0 \pm 0.7^{\mathrm{c}}$ & $6.0 \pm 0.0^{\mathrm{d}}$ \\
Amplitude of pulses (ng/ml) & $3.1 \pm 0.4^{\mathrm{a}}$ & $5.3 \pm 0.4^{\mathrm{b}}$ \\
\hline
\end{tabular}

a,b Differs $P<0.005$; ${ }^{\mathrm{c}, \mathrm{d}}$ Differs $P<0.02$. 

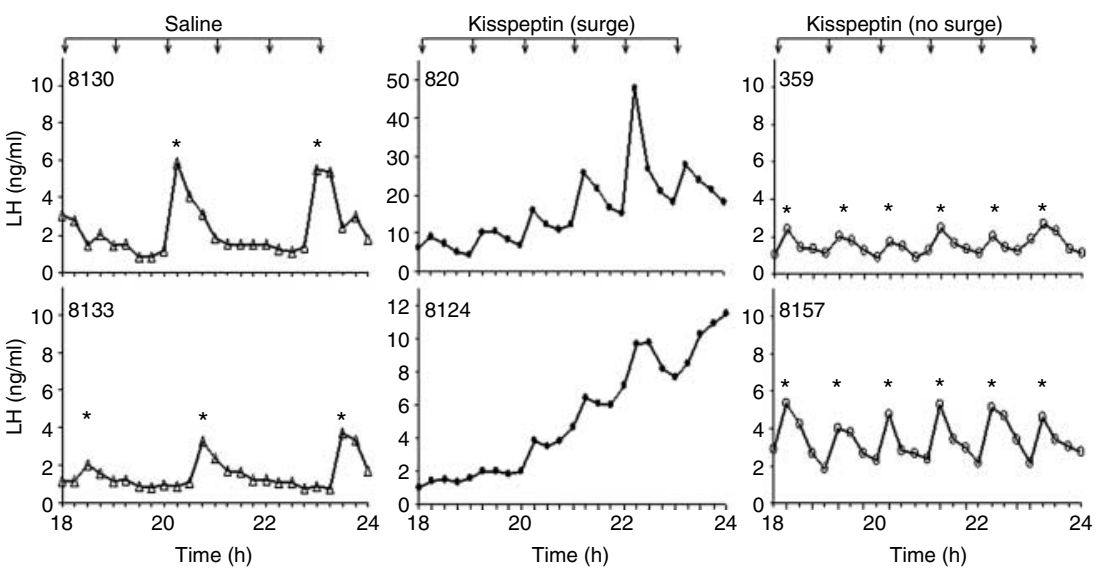

Figure 2 Patterns of $\mathrm{LH}$ release in representative saline- (control) and kisspeptin-treated ewe lambs during period III (18-24 h) of the experiment. Asterisks indicate detected pulses of $\mathrm{LH}$; arrows indicate the time of injections of saline (control) or kisspeptin. Note that Yaxes for lambs 820 and 8124 differ from the others.

extended these findings by demonstrating that intermittent injections of kisspeptin elicit pulse-like release of LH in prepubertal ewe lambs. Moreover, hourly injections of kisspeptin administered for $24 \mathrm{~h}$ stimulated ovarian function in prepubertal lambs leading to enhanced ovarian steroidogenesis, stimulation of a preovulatory surge of $\mathrm{LH}$ and ovulation/luteal activity. The ability of kisspeptin to advance the onset of puberty has been suggested by observations that it induces early vaginal canalization in rats, a physiological event that precedes the first estrous cycle in female rats (Navarro et al. 2004b). Although in our studies kisspeptin treatment stimulated ovulation/luteinization in prepubertal ewes, duration of luteal activity was brief (2-3 days), and the age at establishment of regular estrous cycles was not advanced as hypothesized.

Kisspeptin is a potent stimulator of $\mathrm{LH}$ release in various mammalian and non-mammalian species (Caraty \& Franceschini 2008, Clarkson \& Herbison 2009, Elizur 2009). Although our studies did not distinguish the site of kisspeptin actions, the effects of kisspeptin on stimulating the release of $\mathrm{LH}$ in prepubertal ewe lambs are likely mediated by direct actions upon GNRH neurons. Kisspeptin receptor is present in GNRH neurons (Seminara et al. 2003, Messager et al. 2005), and kisspeptin administered centrally (Messager et al. 2005) or intravenously (Caraty et al. 2007) stimulates the release of GNRH. Moreover, kisspeptin stimulation of $\mathrm{LH}$ release is blocked by GNRH antagonist (Gottsch et al. 2004, Navarro et al. 2004b, Plant et al. 2006) and by passive immunization with GNRH antiserum (Arreguin-Arevalo et al. 2007). However, direct effects of kisspeptin at the adenohypophysis to stimulate $\mathrm{LH}$ release cannot be discounted. Kisspeptin receptor is also expressed in various tissues, including the adenohypophysis (GutierrezPascual et al. 2007), and in vitro studies demonstrate that kisspeptin induces LH release in primary culture of adenohypophyseal cells (Smith et al. 2008). Nevertheless, the physiological relevance for the direct effects of kisspeptin in the adenohypophysis remains controversial, because kisspeptin failed to stimulate the release of $\mathrm{LH}$ in hypothalamo-hypophyseal disconnected ewes (Smith et al. 2008).

In this study, repetitive hourly injections of kisspeptin in prepubertal ewe lambs elicited episodes of $\mathrm{LH}$ release similar to intermittent injections of kisspeptin in agonadal, male monkeys (Plant et al. 2006). In controltreated ewe lambs, spontaneous pulses of $\mathrm{LH}$ were observed to vary in frequency characteristic of ewe lambs at this age. Because all episodes of $\mathrm{LH}$ release observed in kisspeptin-treated lambs occurred immediately after kisspeptin injections and no additional

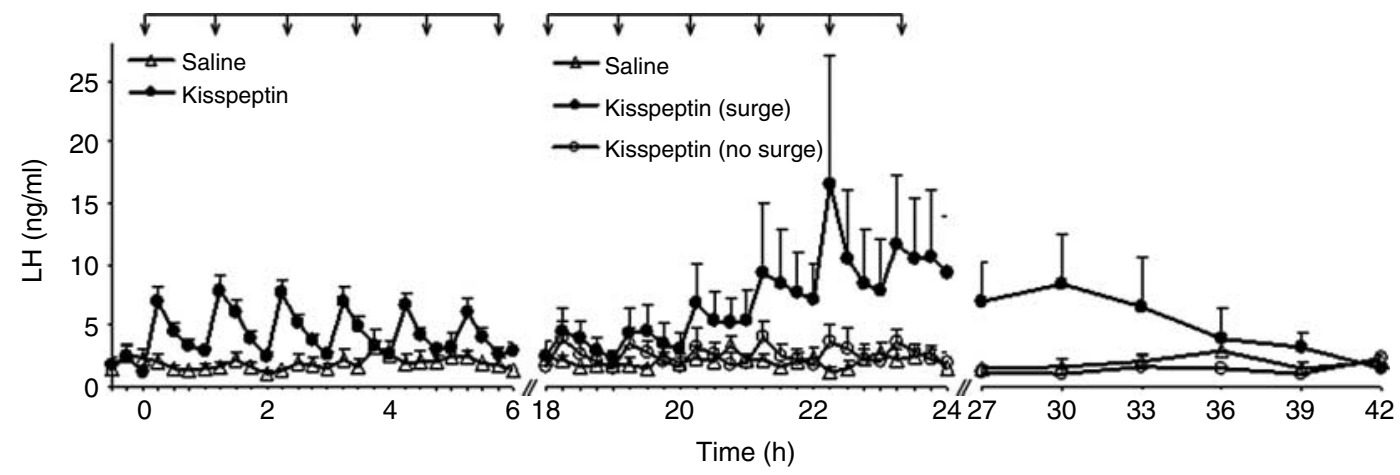

Figure 3 Mean ( \pm s.E.M.) concentrations of LH in saline- (control) and kisspeptin-treated ewe lambs. Arrows indicate hourly injections of saline (control) or kisspeptin. 


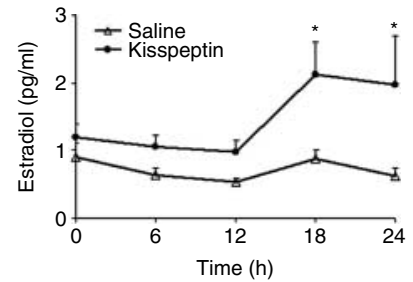

Figure 4 Mean ( \pm S.E.M.) concentrations of estradiol in saline- (control) and kisspeptin-treated ewe lambs during the first $24 \mathrm{~h}$ of treatments. Asterisks indicate differences $(P<0.02)$ between kisspeptin and saline treatments.

secondary LH pulses between kisspeptin injections were detected, we speculate that kisspeptin may be involved in the neuronal pathways leading to synchronized episodic release of GNRH. There is evidence to indicate that GNRH neurons have an intrinsic ability to generate pulses (Wetsel et al. 1992, Terasawa et al. 1999); however, pulses of GNRH release may be entrained by actions of various neurochemicals, including neurotransmitters and glial-derived factors (Moenter et al. 2003, Ojeda et al. 2008). Kisspeptin has been shown to act directly on GNRH neurons, as well as via transsynaptic pathways involving GABAergic and glutamatergic afferents (Pielecka-Fortuna et al. 2008, Pielecka-Fortuna \& Moenter 2010). Therefore, kisspeptin may play a role in synchronizing episodic release of GNRH by acting at multiple levels, including direct stimulation of GNRH neuronal activity, and by modulating GNRH neuron afferents.

The mode of kisspeptin treatment used in this study differs from other studies using constant infusion (Messager et al. 2005, Shahab et al. 2005, Caraty et al. 2007). In monkeys, after an initial increase, concentrations of $\mathrm{LH}$ decreased with continuous infusion of kisspeptin and were not different than controls within $24 \mathrm{~h}$ (Seminara et al. 2006). Although a single bolus of kisspeptin failed to release LH during continuous administration of kisspeptin, $\mathrm{N}$-methyl-D-aspartate (NMDA), a known GNRH secretagogue, and GNRH elicited LH release (Seminara et al. 2006). This observation indicates that the kisspeptin receptor is desensitized by continuous kisspeptin treatment. The mechanisms of kisspeptin receptor desensitization are not clear but seem to involve G-protein-coupled receptor (GPCR) kinase 2 (Pampillo et al. 2009). In sheep, concentrations of $\mathrm{LH}$ also decrease during continuous infusion of kisspeptin (Messager et al. 2005); however, low doses of kisspeptin infused constantly increase concentrations of $E_{2}$ in circulation and stimulate ovulation in anestrous ewes (Caraty et al. 2007, Sebert et al. 2010). Moreover, in peripubertal female rats, circulating concentrations of $\mathrm{LH}$ remained elevated after 7 days of continuous intracerebral infusion of kisspeptin in peripubertal female rats, an effect not observed in cyclic rats (Roa et al. 2008). Therefore, within a specific range of concentrations and depending on developmental stage, continuous infusion of kisspeptin for extended periods can stimulate secretion of GNRH. Nevertheless, endogenous kisspeptin release in the median eminence seems to be episodic (Keen et al. 2008), and this mode of action may be relevant for a fine control of GNRH neuronal activity.

It has been proposed that proper activation of the kisspeptin system is essential for normal pubertal onset (Seminara et al. 2003, Navarro et al. 2004a, Shahab et al. 2005). Increases in kisspeptin gene expression (Navarro et al. 2004a, Shahab et al. 2005) and peptide (Clarkson et al. 2009) have been associated with pubertal development. Recent studies using a kisspeptin antagonist support the requirement for kisspeptin signaling in timing puberty in female rats (Pineda et al. 2010). In ewe lambs, initiation of frequent pulsatile LH release is associated with increases in expression of KISS1 in the arcuate nucleus (Amstalden et al. 2010). Therefore, kisspeptin stimulation of GNRH neuronal function may be critical for pubertal transition toward patterns of pulsatile LH release that support final stages of follicle development ( $\sim 1$ pulse/h in the sheep) and establishment of regular estrous cycles. The current experiment supports this hypothesis by demonstrating that episodic stimulation of LH release by kisspeptin is effective to induce gonadal activity in prepubertal ewe lambs.

$\mathrm{LH}$ stimulation is crucial for increased follicular $\mathrm{E}_{2}$ synthesis and sustained elevated concentrations of $\mathrm{E}_{2}$ that lead to the preovulatory surge of LH. The ability of $E_{2}$ to induce $\mathrm{LH}$ surge develops early during the juvenile period (Foster \& Karsch 1975, Andrews et al. 1981). Thus, $E_{2}$ positive feedback is not the limiting factor in the initiation of regular ovulatory cycles. In 18-week-old ewes, hourly injections of LH for $48 \mathrm{~h}$ stimulated elevations in circulating $\mathrm{E}_{2}$, and surges of LH occurred between 23 and $55 \mathrm{~h}$ after initiation of LH injections in four of seven lambs (Foster et al. 1984). Ovulation was followed by increases in circulating concentrations of progesterone that remained elevated for a full normal-length luteal phase in only one lamb. Similar results were observed in this study using hourly injections of kisspeptin, in which $\sim 70 \%$ of kisspeptintreated ewe lambs exhibited luteal activity. Therefore, follicular development, increased steroidogenesis, and ovulation were achieved by intermittent kisspeptin injections. In contrast to the earlier study (Foster et al. 1984), establishment of full-length luteal phase and regular estrous cycles was not induced in this study, indicating a requirement for additional maturation of neuroendocrine functions upstream to GNRH neurons.

In this study, two ewe lambs had the onset of the LH surge during the second period of intensive blood sampling at the end of kisspeptin treatment. Interestingly, despite escalating concentrations of $\mathrm{LH}$ in circulation, clear elevations in LH were observed in association with kisspeptin injections. This pattern of secretion differs from the usual preovulatory surge of LH lacking clearly 
detectable pulses (Moenter et al. 1991). Our observation in this study may reflect differential actions of kisspeptin in distinct populations of GNRH neurons. During the preovulatory $\mathrm{LH}$ surge, $\sim 40 \%$ of GNRH neurons contain immunoreactive FOS (Lee et al. 1990, Moenter et al. 1993), indicating that only a subpopulation of GNRH neurons is activated. Moreover, in sheep, GNRH neurons dispersed throughout the preoptic area, and hypothalamus become activated during the $\mathrm{LH}$ surge (Moenter et al. 1993), whereas GNRH neurons residing mainly in the mediobasal hypothalamus are activated during the pulsatile release of LH (Boukhliq et al. 1999). Alternatively, exogenous kisspeptin may have exerted its actions on distinct cellular sites (e.g., cell bodies/ dendrites or terminals) to stimulate the release of GNRH during the surge induced by $E_{2}$. It has been demonstrated that kisspeptin can stimulate GNRH release by a direct action at GNRH nerve terminals (d'Anglemont de Tassigny et al. 2008). Therefore, pulses of $\mathrm{LH}$ that appeared superimposed during the surge of $\mathrm{LH}$ secretion in the two lambs may reflect actions of exogenous kisspeptin at this level.

There is compelling evidence for a role of kisspeptin in mediating $E_{2}$ positive feedback on GNRH release. In rodents, the population of kisspeptin neurons in the anteroventral periventricular area (AVPV) seems to be particularly relevant. $E_{2}$ stimulates Kiss 1 expression in the AVPV (Smith et al. 2005), kisspeptin neurons in the AVPV express the immediate-early gene Fos (CFOs) during LH surge (Smith et al. 2006), and immunoneutralization of kisspeptin in the preoptic area (POA) blocks the preovulatory surge of GNRH (Kinoshita et al. 2005). In sheep, the involvement of POA kisspeptin neurons in the $E_{2}$ positive feedback is less clear. Recent observations suggest that kisspeptin neurons in the caudal arcuate nucleus are involved in the $E_{2}$ positive feedback (Smith et al. 2009a). Nevertheless, kisspeptin neurons in the POA of sheep may also be involved in the preovulatory surge of GNRH/LH, because KISS1 expression increases in the POA of ewes just before ovulation. Moreover, increase in FOS immunoreactivity was observed in POA kisspeptin neurons at the time of the surge (Hoffman et al. 2011).

Formation of the corpus luteum after ovulation and initial secretion of progesterone do not require hypophyseal hormones (Yuh et al. 1984). However, adequate LH stimulation is required for maintenance of normal luteal function (Hutchison et al. 1986). In the current experiment, ewes that ovulated following kisspeptin treatment had only a brief period of elevated progesterone. This short period of luteal activity may reflect insufficient release of $\mathrm{LH}$ after termination of kisspeptin treatment. Although short luteal phases are commonly observed in ewes undergoing pubertal transition, it is often followed immediately by another ovulation and a normal-length estrous cycle (Foster \& Jackson 2006). The lack of immediate establishment of regular estrous cycles in ewe lambs ovulating following kisspeptin treatment in this study indicates that the reproductive neuroendocrine axis was not yet fully mature. This observation corresponds to findings reported by Wildt et al. (1980) demonstrating that regular menstrual cycles induced by pulsatile GNRH in immature monkeys ceased with termination of $\mathrm{GNRH}$ treatments.

In summary, injection of kisspeptin stimulated the release of $\mathrm{LH}$ in prepubertal ewe lambs. Intermittent treatments with kisspeptin that create hourly pulses of LH stimulated folliculogenesis and steroidogenesis, and led to the development of the preovulatory LH surge and ovulation. However, luteal activity following induced ovulation was limited, and regular estrous cycles were not established immediately in the absence of kisspeptin treatments. Therefore, kisspeptin seems to play a major role in the maturation of the hypothalamic-gonadotropic-gonadal axis by stimulating GNRH neuronal activity and pulsatile release of $\mathrm{LH}$ during the onset of puberty in ewe lambs.

\section{Materials and Methods}

\section{Animals and experimental procedures}

Experimental procedures involving animals were performed at the Texas A\&M University O.D. Buttler Animal Science Teaching and Research Complex, College Station, TX, USA. The Institutional Agricultural Animal Care and Use Committee of the Texas A\&M University System approved all procedures used in these studies.

A total of twelve intact, spring-born, Suffolk ewe lambs, weaned at 8 weeks of age, were used for this study. Ewe lambs were fed ad libitum a complete-mixed diet containing $16 \%$ $\mathrm{CP}$ and $2.8 \mathrm{MCal} / \mathrm{kg}$ formulated to promote weight gain of $\sim 0.2-0.25 \mathrm{~kg} /$ day. Ewe lambs were housed in partially covered pens and had free access to water and a mineral supplement. At 26 weeks of age, lambs were brought into indoor pens and acclimated to experimental conditions (periodic loose restraint with halter) for 2 weeks. At 28 weeks of age, ewe lambs were assigned randomly to one of two groups: 1$)$ control $(n=6)$ or 2$)$ kisspeptin $(n=6)$. On the day before the onset of treatments, lambs were fitted with a jugular catheter. On the next day, ewe lambs were injected i.v. with either saline (solution containing $0.9 \% \mathrm{NaCl}, \mathrm{w} / \mathrm{v}$; control) or saline containing $20 \mu \mathrm{g}$ of a decapeptide representing the carboxyl terminus of the ovine kisspeptin (kisspeptin; Arreguin-Arevalo et al. 2007) every $1 \mathrm{~h}$ for $24 \mathrm{~h}$. Kisspeptin decapeptide was obtained by custom synthesis (American Peptide Company, Inc., Sunnyvale, CA, USA). Synthesized peptide was $96.5 \%$ pure based on HPLC analysis and had 1318.4 amu of molecular weight based on mass spectral analysis. The dose of kisspeptin used in this experiment was determined based on previous reports demonstrating the effectiveness of kisspeptin to stimulate the release of $\mathrm{LH}$ in sheep (Caraty et al. 2007).

Blood samples $(5 \mathrm{ml})$ were collected from the jugular vein every 15 min starting $30 \mathrm{~min}$ before the first injection of saline or kisspeptin (period 0) and continued for $6 \mathrm{~h}$ at $15 \mathrm{~min}$ intervals (period I). Between 6 and $18 \mathrm{~h}$ from the onset of 
treatments (period II), blood samples were collected just prior to each hourly injection. Collection of blood samples at $15 \mathrm{~min}$ intervals resumed $18 \mathrm{~h}$ after the start of treatments and continued for an additional $6 \mathrm{~h}$ (period III). Following the $24 \mathrm{~h}$ administration of treatments, blood samples were collected every $3 \mathrm{~h}$ for $36 \mathrm{~h}$ (period IV), daily for the next 15 days and then every 3 days until the ewe lambs were detected pubertal or reached 35 weeks of age.

Intensive (every $15 \mathrm{~min}$ ), hourly, and 3-hourly blood samples were placed in tubes containing $50 \mu \mathrm{l}$ solution of heparin $(3000 \mathrm{U} / \mathrm{ml})$ and 5\% EDTA. Jugular catheters were flushed with physiological saline solution after every sampling and with heparinized saline every $1 \mathrm{~h}$ to prevent clotting of the catheter. Daily and 3-daily blood samples were collected by jugular venipuncture. Blood samples were chilled on ice until centrifugation at $1500 \mathrm{~g}$ for $20 \mathrm{~min}$ at $4^{\circ} \mathrm{C}$, and plasma or serum was collected and stored at $-20^{\circ} \mathrm{C}$ until processed for determination of concentrations of $\mathrm{LH}, \mathrm{E}_{2}$, and progesterone by RIA.

\section{$\boldsymbol{R I A}$}

Concentrations of $\mathrm{LH}$ were determined by a double antibody RIA using rabbit anti-ovine LH (AFP192279; National Hormone and Peptide Program, Torrance, CA, USA) at a dilution of 1:1 250 000. A highly purified ovine LH (AFP8614B; National Hormone and Pituitary Program) was used for both as the iodinated tracer and the reference standard preparation. Sensitivity of the assay was $0.2 \mathrm{ng} / \mathrm{ml}$, and the curve was linear to $50 \mathrm{ng} / \mathrm{ml}$. The intra- and inter-assay coefficients of variation averaged 11 and $13.5 \%$ respectively.

Concentrations of $E_{2}$ were determined in plasma extracts using a double antibody RIA (Estradiol double antibody; Siemens, Los Angeles, CA, USA). Extraction was performed in duplicates of $1 \mathrm{ml}$ plasma and reference samples using $4 \mathrm{ml}$ methyl-tert-butyl ether (MTBE). Solvent extracts were dried using nitrogen gas, and the extracts were rehydrated with $200 \mu \mathrm{l}$ ' 0 ' calibrator provided with RIA kit. The assay was performed as per the manufacturer's instructions with the addition of a $1 \mathrm{pg} / \mathrm{ml}$ standard. Concentrations of $E_{2}$ in samples were determined in a single assay, which yielded $43 \%$ binding at $\mathrm{B} / \mathrm{O}$ and detection limit of $0.5 \mathrm{pg} /$ tube at $90 \%$ biding. Extraction efficiency averaged $73 \%$, and estimates of blank extracts averaged $99.8 \%$ binding. The intra-assay coefficient of variation for reference samples averaged $5 \%$.

Concentrations of progesterone were determined in blood samples using a solid-phase RIA (Coat-A-Count; Siemens). The detection limit of the assay was $0.1 \mathrm{ng} / \mathrm{ml}$. The intra- and interassay coefficients of variation for reference samples averaged 7.5 and $24 \%$ respectively.

\section{Statistical analyses}

Frequency and amplitude of LH pulses were determined using a pulse detection algorithm (Pulsefit 1.2; (Kushler \& Brown 1991)). LH data were analyzed using the Proc Mixed procedures for repeated measures of SAS (SAS 9.1; SAS Institute, Cary, NC, USA). The main effects of treatment (saline or kisspeptin) on mean concentrations of $\mathrm{LH}$ and on the frequency and amplitude of LH pulses were compared using period (I: 0-6 h and III: 18-24 h) as repeated variable and ewe (treatment) as the subject. The proportions of ewes in each treatment exhibiting a surge-like release of $\mathrm{LH}$ and elevated circulating progesterone 5 days after the onset of treatments were analyzed by Fisher's exact test procedure of SAS.

\section{Declaration of interest}

The authors declare that there is no conflict of interest that could be perceived as prejudicing the impartiality of the research reported.

\section{Funding}

This work was partly supported by TEX09202 and Texas AgriLife Research (M Amstalden).

\section{Acknowledgements}

The authors would like to acknowledge the assistance of Dr Shawn Ramsey, Colt Sharpen and Kenton Krueger, Department of Animal Science, Texas A\&M University, in this study and $\operatorname{Dr}$ A F Parlow, NIDDK National Hormone and Peptide Program, for providing ovine LH RIA reagents.

\section{References}

Amstalden M, Redmond JS, Baez-Sandoval GM, Spell KM, Spencer TE, Lents CA \& Williams GL 2010 Kiss 1 gene expression in the arcuate nucleus increases during activation of pulsatile release of $\mathrm{LH}$ in maturing ewe lambs. Proceedings of the International Congress Neuroendocrinology, Tours, France. Abstract P1-3.

Andrews WW, Mizejewski GJ \& Ojeda SR 1981 Development of estradiolpositive feedback on luteinizing hormone release in the female rat: a quantitative study. Endocrinology 109 1404-1413. (doi:10.1210/endo109-5-1404)

d'Anglemont de Tassigny X, Fagg LA, Dixon JP, Day K, Leitch HG, Hendrick AG, Zahn D, Franceschini I, Caraty A, Carlton MB et al. 2007 Hypogonadotropic hypogonadism in mice lacking a functional Kiss1 gene. PNAS 104 10714-10719. (doi:10.1073/pnas.0704114104)

d'Anglemont de Tassigny X, Fagg LA, Carlton MB \& Colledge WH 2008 Kisspeptin can stimulate gonadotropin-releasing hormone $(\mathrm{GnRH})$ release by a direct action at $\mathrm{GnRH}$ nerve terminals. Endocrinology 149 3926-3932. (doi:10.1210/en.2007-1487)

Arreguin-Arevalo JA, Lents CA, Farmerie TA, Nett TM \& Clay CM 2007 KiSS-1 peptide induces release of $\mathrm{LH}$ by a direct effect on the hypothalamus of ovariectomized ewes. Animal Reproduction Science 101 265-275. (doi:10.1016/j.anireprosci.2006.09.021)

Boukhliq R, Goodman RL, Berriman SJ, Adrian B \& Lehman MN 1999 A subset of gonadotropin-releasing hormone neurons in the ovine medial basal hypothalamus is activated during increased pulsatile luteinizing hormone secretion. Endocrinology 140 5929-5936. (doi:10.1210/en. 140.12.5929)

Caraty A \& Franceschini I 2008 Basic aspects of the control of GnRH and LH secretions by kisspeptin: potential applications for better control of fertility in females. Reproduction in Domestic Animals $\mathbf{4 3}$ (Supplement 2) 172-178. (doi:10.1111/j.1439-0531.2008.01158.x)

Caraty A, Smith JT, Lomet D, Ben Said S, Morrissey A, Cognie J, Doughton B, Baril G, Briant C \& Clarke IJ 2007 Kisspeptin synchronizes preovulatory surges in cyclical ewes and causes ovulation in seasonally acyclic ewes. Endocrinology 148 5258-5267. (doi:10.1210/en.20070554) 
Castellano JM, Navarro VM, Fernandez-Fernandez R, Nogueiras $R$, Tovar S, Roa J, Vazquez MJ, Vigo E, Casanueva FF, Aguilar E et al. 2005 Changes in hypothalamic KiSS-1 system and restoration of pubertal activation of the reproductive axis by kisspeptin in undernutrition. Endocrinology 146 3917-3925. (doi:10.1210/en.2005-0337)

Clarkson J \& Herbison AE 2009 Oestrogen, kisspeptin, GPR54 and the preovulatory luteinising hormone surge. Journal of Neuroendocrinology 21 305-311. (doi:10.1111/j.1365-2826.2009.01835.x)

Clarkson J, Boon WC, Simpson ER \& Herbison AE 2009 Postnatal development of an estradiol-kisspeptin positive feedback mechanism implicated in puberty onset. Endocrinology 150 3214-3220. (doi:10. 1210/en.2008-1733)

Ebling FJ, Kushler RH \& Foster DL 1990 Pulsatile LH secretion during sexual maturation in the female sheep: photoperiodic regulation in the presence and absence of ovarian steroid feedback as determined in the same individual. Neuroendocrinology 52 229-237. (doi:10.1159/000125591)

Elizur A 2009 The KiSS1/GPR54 system in fish. Peptides 30 164-170. (doi:10.1016/j.peptides.2008.08.018)

Foster DL \& Jackson LM 2006 Puberty in the sheep. In Knobil and Neill's Physiology of Reproduction, 3rd edn, pp 2127-2176. Ed JD Neill. St Louis: Elsevier Academic Press. (doi:10.1016/B978-012515400-0/ 50044-0)

Foster DL \& Karsch FJ 1975 Development of the mechanism regulating the preovulatory surge of luteinizing hormone in sheep. Endocrinology 97 1205-1209. (doi:10.1210/endo-97-5-1205)

Foster DL, Lemons JA, Jaffe RB \& Niswender GD 1975 Sequential patterns of circulating luteinizing hormone and follicle-stimulating hormone in female sheep from early postnatal life through the first estrous cycles. Endocrinology 97 985-994. (doi:10.1210/endo-97-4-985)

Foster DL, Ryan KD \& Papkoff H 1984 Hourly administration of luteinizing hormone induces ovulation in prepubertal female sheep. Endocrinology 115 1179-1185. (doi:10.1210/endo-115-3-1179)

Gottsch ML, Cunningham MJ, Smith JT, Popa SM, Acohido BV, Crowley WF, Seminara S, Clifton DK \& Steiner RA 2004 A role for kisspeptins in the regulation of gonadotropin secretion in the mouse. Endocrinology 145 4073-4077. (doi:10.1210/en.2004-0431)

Gutierrez-Pascual E, Martinez-Fuentes AJ, Pinilla L, Tena-Sempere M, Malagon MM \& Castano JP 2007 Direct pituitary effects of kisspeptin: activation of gonadotrophs and somatotrophs and stimulation of luteinising hormone and growth hormone secretion. Journal of Neuroendocrinology 19 521-530. (doi:10.1111/j.1365-2826.2007. 01558.x)

Hoffman GE, Le WW, Franceschini I, Caraty A \& Advis JP 2011 Expression of fos and in vivo median eminence release of LHRH identifies an active role for preoptic area kisspeptin neurons in synchronized surges of $\mathrm{LH}$ and LHRH in the ewe. Endocrinology 152 214-222. (doi:10.1210/ en.2010-0066)

Huffman LJ, Inskeep EK \& Goodman RL 1987 Changes in episodic luteinizing hormone secretion leading to puberty in the lamb. Biology of Reproduction 37 755-761. (doi:10.1095/biolreprod37.4.755)

Hutchison JS, Nelson PB \& Zeleznik AJ 1986 Effects of different gonadotropin pulse frequencies on corpus luteum function during the menstrual cycle of rhesus monkeys. Endocrinology 119 1964-1971. (doi:10.1210/endo-119-5-1964)

Kadokawa H, Matsui M, Hayashi K, Matsunaga N, Kawashima C, Shimizu T, Kida K \& Miyamoto A 2008 Peripheral administration of kisspeptin-10 increases plasma concentrations of $\mathrm{GH}$ as well as $\mathrm{LH}$ in prepubertal Holstein heifers. Journal of Endocrinology 196 331-334. (doi:10.1677/JOE-07-0504)

Keen KL, Wegner FH, Bloom SR, Ghatei MA \& Terasawa E 2008 An increase in kisspeptin-54 release occurs with the pubertal increase in luteinizing hormone-releasing hormone-1 release in the stalk-median eminence of female rhesus monkeys in vivo. Endocrinology 149 4151-4157. (doi:10.1210/en.2008-0231)

Kinder JE, Bergfeld EG, Wehrman ME, Peters KE \& Kojima FN 1995 Endocrine basis for puberty in heifers and ewes. Journal of Reproduction and Fertility. Supplement 49 393-407.

Kinoshita M, Tsukamura H, Adachi S, Matsui H, Uenoyama $Y$, Iwata K, Yamada S, Inoue K, Ohtaki T, Matsumoto H et al. 2005 Involvement of central metastin in the regulation of preovulatory luteinizing hormone surge and estrous cyclicity in female rats. Endocrinology $\mathbf{1 4 6}$ 4431-4436. (doi:10.1210/en.2005-0195)
Kushler RH \& Brown MB 1991 A model for the identification of hormone pulses. Statistics in Medicine 10 329-340. (doi:10.1002/sim. 4780100305)

Lapatto R, Pallais JC, Zhang D, Chan YM, Mahan A, Cerrato F, Le WW, Hoffmann GE \& Seminara SB 2007 Kiss $1^{-1-}$ mice exhibit more variable hypogonadism than Gpr54 ${ }^{-1-}$ mice. Endocrinology 148 4927-4936. (doi:10.1210/en.2007-0078)

Lee WS, Smith MS \& Hoffman GE 1990 Luteinizing hormone-releasing hormone neurons express Fos protein during the proestrous surge of luteinizing hormone. PNAS 87 5163-5167. (doi:10.1073/pnas.87.13.5163)

Lents CA, Heidorn NL, Barb CR \& Ford JJ 2008 Central and peripheral administration of kisspeptin activates gonadotropin but not somatotropin secretion in prepubertal gilts. Reproduction 135 879-887. (doi:10.1530/ REP-07-0502)

Magee C, Foradori CD, Bruemmer JE, Arreguin-Arevalo JA, McCue PM, Handa RJ, Squires EL \& Clay CM 2009 Biological and anatomical evidence for kisspeptin regulation of the hypothalamic-pituitarygonadal axis of estrous horse mares. Endocrinology 150 2813-2821. (doi:10.1210/en.2008-1698)

Matsui H, Takatsu Y, Kumano S, Matsumoto H \& Ohtaki T 2004 Peripheral administration of metastin induces marked gonadotropin release and ovulation in the rat. Biochemical and Biophysical Research Communications 320 383-388. (doi:10.1016/j.bbrc.2004.05.185)

Messager S, Chatzidaki EE, Ma D, Hendrick AG, Zahn D, Dixon J, Thresher RR, Malinge I, Lomet D, Carlton MB et al. 2005 Kisspeptin directly stimulates gonadotropin-releasing hormone release via G protein-coupled receptor 54. PNAS 102 1761-1766. (doi:10.1073/ pnas.0409330102)

Moenter SM, Caraty A, Locatelli A \& Karsch FJ 1991 Pattern of gonadotropin-releasing hormone $(\mathrm{GnRH})$ secretion leading up to ovulation in the ewe: existence of a preovulatory GnRH surge. Endocrinology 129 1175-1182. (doi:10.1210/endo-129-3-1175)

Moenter SM, Karsch FJ \& Lehman MN 1993 Fos expression during the estradiol-induced gonadotropin-releasing hormone $(\mathrm{GnRH})$ surge of the ewe: induction in GnRH and other neurons. Endocrinology 133 896-903. (doi:10.1210/en.133.2.896)

Moenter SM, DeFazio AR, Pitts GR \& Nunemaker CS 2003 Mechanisms underlying episodic gonadotropin-releasing hormone secretion. Frontiers in Neuroendocrinology 24 79-93. (doi:10.1016/S0091-3022 (03)00013-X)

Navarro VM, Castellano JM, Fernandez-Fernandez R, Barreiro ML, Roa J, Sanchez-Criado JE, Aguilar E, Dieguez C, Pinilla L \& Tena-Sempere M 2004a Developmental and hormonally regulated messenger ribonucleic acid expression of KiSS-1 and its putative receptor, GPR54, in rat hypothalamus and potent luteinizing hormone-releasing activity of KiSS-1 peptide. Endocrinology 145 4565-4574. (doi:10.1210/en.2004-0413)

Navarro VM, Fernandez-Fernandez R, Castellano JM, Roa J, Mayen A, Barreiro ML, Gaytan F, Aguilar E, Pinilla L, Dieguez C et al. 2004b Advanced vaginal opening and precocious activation of the reproductive axis by KiSS-1 peptide, the endogenous ligand of GPR54. Journal of Physiology 561 379-386. (doi:10.1113/jphysiol.2004.072298)

Ojeda SR, Lomniczi A \& Sandau US 2008 Glial-gonadotrophin hormone $(\mathrm{GnRH})$ neurone interactions in the median eminence and the control of GnRH secretion. Journal of Neuroendocrinology 20 732-742. (doi:10. 1111/j.1365-2826.2008.01712.x)

Pampillo M, Camuso N, Taylor JE, Szereszewski JM, Ahow MR, Zajac M, Millar RP, Bhattacharya M \& Babwah AV 2009 Regulation of GPR54 signaling by GRK2 and $\beta$-arrestin. Molecular Endocrinology 23 2060-2074. (doi:10.1210/me.2009-0013)

Pielecka-Fortuna J \& Moenter SM 2010 Kisspeptin increases $\gamma$-aminobutyric acidergic and glutamatergic transmission directly to gonadotropin-releasing hormone neurons in an estradiol-dependent manner. Endocrinology 151 291-300. (doi:10.1210/en.2009-0692)

Pielecka-Fortuna J, Chu Z \& Moenter SM 2008 Kisspeptin acts directly and indirectly to increase gonadotropin-releasing hormone neuron activity and its effects are modulated by estradiol. Endocrinology $\mathbf{1 4 9}$ 1979-1986. (doi:10.1210/en.2007-1365)

Pineda R, Garcia-Galiano D, Roseweir A, Romero M, SanchezGarrido MA, Ruiz-Pino F, Morgan K, Pinilla L, Millar RP \& TenaSempere M 2010 Critical roles of kisspeptins in female puberty and preovulatory gonadotropin surges as revealed by a novel antagonist. Endocrinology 151 722-730. (doi:10.1210/en.2009-0803) 
Plant TM, Ramaswamy S \& Dipietro MJ 2006 Repetitive activation of hypothalamic $G$ protein-coupled receptor 54 with intravenous pulses of kisspeptin in the juvenile monkey (Macaca mulatta) elicits a sustained train of gonadotropin-releasing hormone discharges. Endocrinology 147 1007-1013. (doi:10.1210/en.2005-1261)

Roa J, Vigo E, Garcia-Galiano D, Castellano JM, Navarro VM, Pineda R, Dieguez C, Aguilar E, Pinilla L \& Tena-Sempere M 2008 Desensitization of gonadotropin responses to kisspeptin in the female rat: analyses of $\mathrm{LH}$ and FSH secretion at different developmental and metabolic states. American Journal of Physiology. Endocrinology and Metabolism 294 E1088-E1096. (doi:10.1152/ajpendo.90240.2008)

de Roux N, Genin E, Carel JC, Matsuda F, Chaussain JL \& Milgrom E 2003 Hypogonadotropic hypogonadism due to loss of function of the KiSS1-derived peptide receptor GPR54. PNAS 100 10972-10976. (doi:10.1073/pnas.1834399100)

Sebert ME, Lomet D, Said SB, Monget P, Briant C, Scaramuzzi RJ \& Caraty A 2010 Insights into the mechanism by which kisspeptin stimulates a preovulatory LH surge and ovulation in seasonally acyclic ewes: potential role of estradiol. Domestic Animal Endocrinology 38 289-298. (doi:10.1016/j.domaniend.2010.01.001)

Seminara SB, Messager S, Chatzidaki EE, Thresher RR, Acierno JS Jr, Shagoury JK, Bo-Abbas Y, Kuohung W, Schwinof KM, Hendrick AG et al. 2003 The GPR54 gene as a regulator of puberty. New England Journal of Medicine 349 1614-1627. (doi:10.1056/NEJMoa035322)

Seminara SB, Dipietro MJ, Ramaswamy S, Crowley WF Jr \& Plant TM 2006 Continuous human metastin 45-54 infusion desensitizes $G$ proteincoupled receptor 54-induced gonadotropin-releasing hormone release monitored indirectly in the juvenile male rhesus monkey (Macaca mulatta): a finding with therapeutic implications. Endocrinology 147 2122-2126. (doi:10.1210/en.2005-1550)

Shahab M, Mastronardi C, Seminara SB, Crowley WF, Ojeda SR \& Plant TM 2005 Increased hypothalamic GPR54 signaling: a potential mechanism for initiation of puberty in primates. PNAS 102 2129-2134. (doi:10. 1073/pnas.0409822102)

Smith JT, Cunningham MJ, Rissman EF, Clifton DK \& Steiner RA 2005 Regulation of Kiss1 gene expression in the brain of the female mouse. Endocrinology 146 3686-3692. (doi:10.1210/en.2005-0488)

Smith JT, Popa SM, Clifton DK, Hoffman GE \& Steiner RA 2006 Kiss1 neurons in the forebrain as central processors for generating the preovulatory luteinizing hormone surge. Journal of Neuroscience $\mathbf{2 6}$ 6687-6694. (doi:10.1523/JNEUROSCI.1618-06.2006)
Smith JT, Rao A, Pereira A, Caraty A, Millar RP \& Clarke IJ 2008 Kisspeptin is present in ovine hypophysial portal blood but does not increase during the preovulatory luteinizing hormone surge: evidence that gonadotropes are not direct targets of kisspeptin in vivo. Endocrinology 149 1951-1959. (doi:10.1210/en.2007-1425)

Smith JT, Li Q, Pereira A \& Clarke IJ 2009a Kisspeptin neurons in the ovine arcuate nucleus and preoptic area are involved in the preovulatory luteinizing hormone surge. Endocrinology 150 5530-5538. (doi:10. 1210/en.2009-0712)

Smith JT, Saleh SN \& Clarke IJ 2009b Seasonal and cyclical change in the luteinizing hormone response to kisspeptin in the ewe. Neuroendocrinology 90 283-291. (doi:10.1159/000227806)

Suzuki S, Kadokawa H \& Hashizume T 2008 Direct kisspeptin-10 stimulation on luteinizing hormone secretion from bovine and porcine anterior pituitary cells. Animal Reproduction Science 103 360-365. (doi:10.1016/j.anireprosci.2007.05.016)

Terasawa E, Keen KL, Mogi K \& Claude P 1999 Pulsatile release of luteinizing hormone-releasing hormone (LHRH) in cultured LHRH neurons derived from the embryonic olfactory placode of the rhesus monkey. Endocrinology 140 1432-1441. (doi:10.1210/en.140.3.1432)

Watanabe G \& Terasawa E 1989 In vivo release of luteinizing hormone releasing hormone increases with puberty in the female rhesus monkey. Endocrinology 125 92-99. (doi:10.1210/endo-125-1-92)

Wetsel WC, Valenca MM, Merchenthaler I, Liposits Z, Lopez FJ, Weiner RI, Mellon PL \& Negro-Vilar A 1992 Intrinsic pulsatile secretory activity of immortalized luteinizing hormone-releasing hormone-secreting neurons. PNAS 89 4149-4153. (doi:10.1073/pnas.89.9.4149)

Wildt L, Marshall G \& Knobil E 1980 Experimental induction of puberty in the infantile female rhesus monkey. Science 207 1373-1375. (doi:10. 1126/science.207.4437.1373)

Yuh KC, Bill CH II \& Keyes PL 1984 Transient development and function of rabbit corpora lutea after hypophysectomy. American Journal of Physiology 247 E808-E814.

Received 17 November 2010

First decision 20 December 2010

Accepted 27 January 2011 